\title{
Index to Volume 128
}

\section{Compiled by William Halliday}

Abundance, 1, 327

Abundismus, 63

Ackerman, M.R., 191

Alaska, Fairbanks, 80

Alberta,

Hannah, 145

Southern, 50

Western-Central, 223

Albino, 250

Alien, Invasive, 358

Alvar, 243

Amelanistic, 250

Ammodytes hexapterus, 57

Amos, A., 377

Amphibian, 50, 151

Anadromy, 260

Analysis, Pellet, 393

Anomaly, Colour, 250

Arachnids, 363

Archibald, H.L. The Enigma of the 10-year Wildlife Population Cycle Solved? Evidence that the Periodicity and Regularity of the Cycle Are Driven by a Lunar Zeitgeber, 327-340

Arctic, 269

Ardetta neoxena, 350

Ascalapha odorata, 77

Bags, Leaf Litter, 200

Banding, 135

Barcoding, DNA, 77

Barrier(s), 80

Ecological, 135

Geographic, 135

Bartramia longicauda, 341

Bat(s), 25

Activity, 158

Big Brown, 158

Diet, 158

Eastern Red, 158

Hoary, 158

Bay,

Hudson, 77, 385

of Fundy, 72

Witless, 72

Bear, Grizzly, 223

Behaviour, Destructive, 200

Benthic, 1

Birds,

Breeding, 385

Water, 235

Bittern,

Cory's, 350
Least, 350

Bleeker, W., 385

Bonasa umbellus, 327

Bond, A.L., 72

Breeding, 50

Breeding Bird Survey, 119

British Columbia,

Coastal, 57

Southwestern, 393

Brodo, F., 314, 432

Brooding, 145

Broods, Double, 44

Bubo virginianus, 145, 393

Bunting, Snow, 269

Burbot, 377

Burgess, N.L., 1

Burn, Prescribed, 400

Buteo,

lagopus, 145

regalis 145

Butterflies, Local, 358

Callaghan, C., T. Rytwinski. Editor's Report for Volume 127 (2013), 220-222

Calls, Night-Flight, 135

Cambarus bartonii, 111

Canada, 119

Atlantic, 72

Eastern, 25, 363

Canary, Atlantic, 269

Canis lupus, 189

Capture, Hand, 111

Capture Success, 111, 191

Care, Parental, 145

Carex acutiformis, 358

Carnivora, 25

Catling, P.M. Impact of the 2012 Drought on Woody Vegetation Invading Alvar Grasslands in the Burnt Lands Alvar, Eastern Ontario, 243-249

Catling, P.M., and B. Kostiuk. Use of a Marsh Dominated by the Introduced European Lake Sedge, Carex acutiformis, by Highly Localized Native Butterflies, 358-362

Cavallaro, M.C., A.R. Main, C.A. Morrissey. Muskrat (Ondatra zibethicus) Interference with Aquatic Invertebrate Traps, 200-203

Cedar, Eastern White, 243

Chalmers, L.D., 50

Chelydra serpentina, 179

Chiroptera, 25

Chronology, Denning, 223

Chrysemys picta marginata, 179

Note: Page references are to the first page of the item (e.g., article, note), and as such are not always to the exact word location. 
Cipriani, J., 432

Collar, GPS, 223

Collins, P. A Naturalist for All Seasons: Richard Merrill Saunders, 1904-1998, 289-294

Colouration, 250

Communication, 195

Connectivity, Wetland, 151

Conservation, 50

Cook, F.R. A Tribute to Kenneth William Stewart, 1936-2011, 84-90

Cook, F.R. Retirement of Associate Editor C.D. Bird, 218

Cook, F.R. Obituary - Farley Mowat 1921-2014, 219

Cook, F.R. A Tribute to Warren Baxter Ballard, 19472012, 276-288

Cook, F.R. William Beverly Scot 1917-2014, 431

Corvus brachyrhnchos, 195

County,

Essex, 135

Fayette, 191

Hardeman, 191

Shelby, 191

Court, G.S., 145

Cove, Bird, 77

Crayfish,

Allegheny, 111

Appalachian Brook, 111

Calico, 111

Northern Clearwater, 111

Rusty, 111

Virile, 111

Crow, American, 195

Cylce,

10-year Wildlife, 327

Lunar Nodal, 327

Decline,

Amphibian, 151

Population, 165

Dendrochonology, 243

Dentary, 25

Depredation, Nest, 179

Detection, Predator, 179

Detector, Ultrasonic, 158

Development, Embryo, 50

Devlin, J., 111-118

Dicrostonyx nunatakensis, 265

Diet, 57, 393

Dimorphism, Sexual, 377

Discrimination, Song, 408

Dispersal, 80

Distribution, 1, 77, 204, 265, 363

Divergence, Genetic, 77

Downes, C., 119

Drought, 243

Duncan, J.R., 38

Dussureault, J., 235

Ecology, 179

Egg, 50, 72

Eider, Common, 235
Ekrem, T., P.G. Kevan, T.S. Woodcock, and P.D.N. Hebert. The Most Northerly Black Witch ( $A s^{-}$ calapha odorata): A Tropical Moth in the Canadian Arctic, 77-79

Electrofishing, 111

Elliott, J.E., 393

Elmer, K.R., 377

Entanglement, 173

Eptesicus fuscus, 158

Euphyes dion, 358

Erythristic, 250

Experiment, Playback, 408

Fabianek, F., 25

Farming, Organic, 158

Fauteux, D., G. Lupien, F. Fabianek, J. Gagnon, M. Séguy, and L. Imbeau. An Illustrated Key to the Mandibles of Small Mammals of Eastern Canada, 25-37

Feeding, 145, 189

Feierabend, D., and K. Kielland. Multiple Crossings of a Large Glacial River by Canada Lynx (Lynx canadensis), 80-83

Fish, Freshwater, 377

Fisher, 272

Fishing, Line Hooking, 377

Florida, 350

Food Provisioning, 145

Forest, Boreal, 80

Francis, C.M., 119

Frog,

Boreal Chorus, 151

Northern Leopard, 50

Gagnon, J., 25

Galbraith, M. 57

Gartersnake, Maritime, 63

Geothlypis philadelphia, 408

Gérard, M.A., 145

Gilhen, J., and F.W. Scott. Melanistic Diversity in the Maritime Gartersnake, Thamnophis sirtalis pallidulus, in Nova Scotia, Canada, 63-71

Gilliland, S.G., 235

Graham, H., and G.B. Stenhouse. Home Range, Movements, and Denning Chronology of the Grizzly Bear (Ursus arctos) in West-Central Alberta, 223-234

Grouse, Ruffed, 327

Grousberry, 400

Gull,

Great Black-backed, 165

Herring, 165

Gunson, K., 151

Habitat, 38, 204

Amphibian, 151

Edge, 191

Meso-, 341

Micro-, 341

Winter, 272

Hamer, D., 400

Hanrahan, C., 432 
Hare(s), 25

Arctic, 189

Snowshoe, 327

Harris, L.N., J-S. Moore, C.G. McDermid, and H.K. Swanson. Long-distance Anadromous Migration in a Fresh Water Specialist: the Lake Trout

Hawk, (Salvelinus namaycush), 260-164

Ferruginous, 145

Rough-legged, 145

Hearne, Samuel, 269

Hebert, P.D.N., 77

Hendricks, P., S. Lenard. Pygmy Shrew (Sorex hoyii) in Montana East of the Rocky Mountains with Comments on its Distribution Across the Northern Great Plains, 204-206

Hindmarch, S., and J.E. Elliott. Comparing the Diet of Great Horned Owls (Bubo virginianus) in Rural and Urban Areas of Southwestern British Columbia, 393-399

Hipfner, J.M., and M. Galbraith. Diet of the Pacific Sand Lance (Ammodytes hexapterus) in the Salish Sea, British Columbia, in the 1960s, 57-62

Hudson, M.-A.R., 119

Identification, 25, 250

Imbeau, L., 25

Invasive Species, 111, 358

Iridistic, 250

Island(s),

Belcher, 385

Boot, 165

Coastal, 63

Ellesmere, 189

Gull, 72

Machias Seal, 72

Nastapoka, 385

Pelee, 135

Tukarak, 385

Victoria, 260

Ixobrychus, "neoxenus" exilis, 350

exilis, 350

Jaw, Lower, 25

Jung, T.S., B.G. Slough, D.W. Nagorsen, and P.M.

Kukka. New Records of the Ogilvie Mountains

Collared Lemming (Dicrostonyx nunatakensis) in central Yukon, 265-268

Juniper, Common, 243

Juniperus communis, 243

Kansas, Wichita, 1955

Kennedy, A.C., 165, 191

Kevan, P.G., 77

Key, Dichotomous, 25

Kielland, K., 80

Kostiuk, B., 358

Kukka, P.M., 265

Kurta, A., 158

Labrador, 72, 363

Lac, Guillaume-Delisle, 385

Lagomorpha, 25
Lake(s),

Acidic, 1

Erie, 135

Kawartha, 111

Lance, Pacific Sand, 57

Lane, Flight, 195

Langley, W. Effect of Food Patch Discovery on the Number of American Crows (Corvus brachyrhynchos) Using a Flight Lane, 195-199

Lariurus,

borealis, 158

cinereus, 158

Larus,

marinus, 165

argentatus, 165

Lead-backed, 250

Learning, 189

Lemming(s), 25

Ogilvie Mountain Collared, 265

Lenard, S., 204

Lepus,

americanus, 327

arcticus, 189

Lethe Eurydice, 358

Leucism, 350

Leucistic, 250

Limit, Northern, 341

Lithobates pipiens, 50

Litzgus, J.D., 179

Loche, 377

Long, B.L., A. Kurta. Activity and Diet of Bats in Conventional versus Organic Apple Orchards in Southern Michigan, 158-164

Lota lota, 377

Lupien, G., 25

Lynx, Canada, 80, 327

Lynx canadensis, 80, 327

MacKenzie, A., 432

MacKinnon, C.M., A.C. Kennedy. Decline in Breeding of the Great Black-backed Gull, Larus marinus, and the Herring Gull, L. argentatus, on Boot Island, Nova Scotia, 1986 to 2010, 165-172

Macroinvertebrates, 1

Main, A.R., 200

Maine, Oxbow, 408

Management, 50 Invasive, 358

Mandible, 25

Manitoba, Churchill, 77

Duck Mountain Provincial Park, 408

Northern, 77

Southern, 38, 44

Mariposa de la Muerte, 77

Marsh, Delta, 44

Martes pennant, 272

McDermid, C.G., 260

Mech, L.D. A Gray Wolf (Canis lupus) Delivers Live Prey to a Pup, 189-190 
Melanism, 63, 350

Mosaic, 63

Pure, 63

Melanistic, 250

Predominantly, 63

Mennill, D.J., 135

Mice, 25

Michigan, Southern, 158

Microtus townsendii, 393

Migration, 77, 260

Bird, 135

Migratory, 77

Miller, V., E. Nol, L.P. Nguyen, and D.M. Turner. Habitat Selection and Nest Success of the Upland Sandpiper (Bartramia longicauda) in Ivvavik National Park, Yukon, Canada, 341-349

Minutes of the $135^{\text {th }}$ Annual Business Meeting of the Ottawa Field-Naturalists' Club January 14,

Model, 2014, 314-326

Hierarchical Bayesian, 119

Maximum Likelihood, 119

Moehrenschlager, A., 50

Moles, 25

Monitoring, 111

Acoustic, 135

Population, 119

Small Mammal, 191

Montana,

Eastern, 204

Yellowstone River, 173

Moore, J.-D., and M. Ouellet. A Review of Colour Phenotypes of the Eastern Red-backed Salamander, Plethodon cinereus, in North America, $250-259$

Moore, J.-S., 260

Morph, Colour, 250

Morphometrics, 25

Morrissey, C.A., 200

Mortality, 173

Movement, 223

Murre, Common, 72

Muskeg, 272

Muskrat, 200

Nagorsen, D.W., 265

National Historic Site, Kejimkujik, 1

National Park,

Banff, 400

Ivvavik, 341

Jasper, 223

Kejimkujik, 1

National Wildlife Area, 165

Nelson, W., 145

Nesting, 38, 165

Net, Mist, 44, 158

New Brunswick, 72

New Hampshire, Twin Mountain, 408

Newfoundland, 72, 408

Southeastern, 235

Stephenville Crossing, 408
Nguyen, L.P., 341

Nigrismus, 63

Noakes, D.L.G., and J.D. Noakes. A Note on Bird Song: Samuel Hearne's Observations on the Snow Bunting (Plectrophenax nivalis), 269271

Noakes, J.D., 269

Nol, E., 341

North America, 250

Nova Scotia, 1

Boot Island, 165

Coastal, 63

Eastern, 408

Western, 408

Wreck Cove, 408

Nunavut,

Ellesmere Island, 189

Rankin Inlet, 145

Nussbaumer, C., N.L. Burgess, and R.C. Weeber. Distribution and Abundance of Benthic Macroinvertebrates and Zooplankton in Lakes in Kejimkujik National Park and National Historic Site of Canada, Nova Scotia, 1-24

Obituary, 219

Observations, 145

Ondatra zibethicus, 200

Ontario, 179, 350

Eastern, 243

Marathon, 408

Muskoka/Haliburton, 111

Ottawa, 151, 358

Southwestern, 135

Orchard, Apple, 158

Orconectes,

immunis, 111

obscurus, 111

propinquus, 111

rusticus, 111

virilis, 111

Osprey, 173

Ostovar, K., 173

Ottawa Field-Naturalists' Club Minutes of the $134^{\text {th }}$ Annual Business Meeting, 314-326

Ouellet, M., 250

Owl,

Barred, 38

Great Horned, 145, 393

Pandion haliaetus, 173

Pardy, S., 363

Patch, Food, 195

Pekania pennant, 272

Pengelly, I, and D. Hamer. Grouseberry (Vaccinium scoparium Leiberg ex Coville) Fruit Production in Forest Openings in Banff National Park, Alberta, 400-407

Peninsula, Avalon, 235

Period, Spawning, 50

Perry, R.C., J.R. Pickavance, and S. Pardy. Spiders of the Southern Taiga Biome of Labrador, Canada, 363-376 
Pesticides, 158

Phenology, 50

Phenotype(s), 63, 250

Picea glauca, 243

Pickavance, J.R., 363

Pigment, Black, 63

Pine, Eastern White, 243

Pinus strobus, 243

Pirie-Hay, D.W., and A.L. Bond. Thickness of Common Murre (Uria aalge) Eggshells in Atlantic Canada, 72-76

Pitocchelli, J. Song Discrimination by Male Mourning Warblers (Geothlypis philadelphia) and Implications for Population Divergences across the Breeding Range, 408-415

Plains,

Boreal, 272

Northern Great, 204

Plant, Larval Food, 358

Playback, Audio, 38

Plectrophenax nivalis, 269

Plethodon cinereus, 250

Poanes, massasoit, 358 viator, 358

Pollution, Oil, 235

Population Trend, 119

Potholes, Prairie, 204

Power, K., 235

Predators, 179

Production, Fruit, 400

Proulx, G. Late-winter Habitat Use by the Fisher, Pekania pennant (Erxleben, 1777), in the Boreal Plains Ecozone of Northwestern Saskatchewan, Canada, 272-275

Provincial Park, Algonquin, 179

Cypress Hills, 50

Duck Mountain, 408

Pseudacris maculata, 151

Radiation,

Photosynthetically Active, 400

Solar, 400

Randall, L.A., L.D. Chalmers, A. Moehrenschlager, and A.P. Russell. Asynchronous Breeding and Variable Embryonic Development Period in the Threatened Northern Leopard Frog (Lithobates pipiens) in the Cypress Hills, Alberta, Canada: Conservation and Management Implications, 50-56

Range, Home, 80, 223

Raptor, 38

Rats, 393

Rattus, 393

Recknagel, H., A. Amos, and K.R. Elmer. Morphological and Ecological Variation among Populations and Subspecies of Burbot (Lota lota [L, 1758]) from the Mackenzie River Delta, Canada, 377-384
Recovery, Species, 179

Red-backed, 250

Region, Great Lakes, 243

Reid, S.M., J. Devlin. Effectiveness of Stream Sampling Methods in Capturing Non-native Rusty Crayfish (Orconectes rusticus) in Ontario, 111118

Relationship, Weight-Length, 377

Reserve, Witless Bay Ecological, 72

Restani, M., 173

Riley, J.L., J.D. Litzgus. Cues Used by Predators to Detect Freshwater Turtle, 179-188

River,

Halokvik, 260

Mackenzie, 377

Tanana, 80

Yellowstone, 173

Robertson, G.J., S.G. Gilliland, P.C. Ryan, J. Dussureault, K. Power, and B.C. Turner. Mortality of the Common Eider, Somateria mollissima (Linnaeus, 1758), and other Water Birds during two Inshore Oiling Events in Southeastern Newfoundland, 2005 and 2006, 235-242

Rodentia, 25

Rodenticide, 393

Roost, Winter, 195

Russell, A.P., 50

Ryan, P.C., 235

Rytwinski, T., 220

Salamander,

Eastern Red-backed, 250

Salvelinus namaycush, 260

Sanders, C.E., D.J. Mennill. Acoustic Monitoring of Migratory Birds over Western Lake Erie: Avian Responses to Barriers and the Importance of Islands, 135-144

Sandpiper, Upland, 341

Saskatchewan,

Alvena, 200

Hudson Bay, 408

Northwestern, 272

Saskatoon, 145

Schueler, F.W., 151

Schumtz, J.K., M.A. Gérard, G.S. Court, R.W. Nelson. Parental Care by Lone Male Ferruginous Hawks (Buteo regalis), Rough-legged Hawks (Buteo lagopus), and Great Horned Owls (Bubo virginianus) was Limited to Providing Food, 145-150

Scott, F.W., 63

Sea, Salish, 57

Seacor, R., K. Ostovar, M. Restani. Distribution and Abundance of Baling Twine in the Landscape Near Osprey (Pandion haliaetus) Nests: Implications for Nestling Entanglement, 173-178

Sealy, S.G. Yellow Warbleys (Setophaga petechia) Rear Second Broods in Some Years at Delta Marsh, Manitoba, 44-49

Seburn, D.C., K. Gunson, F.W. Schueler. Apparent Widespread Decline of the Boreal Chorus Frog 
(Pseudacris maculata) in Eastern Ontario, 151157

Sedge, European Lake, 358

Séguy, M., 25

Seining, 111

Selection, Nest-Site, 341

Serinus canaries, 269

Setophaga petechia, 44

Shorebirds, 341

Shrew(s), 25, 204 Pygmy, 204

Size, Egg, 72

Skull, 25

Slough, B.G., 265

Smith, A.C., M.-A.R. Hudson, C. Downes, C.M. Francis. Estimating Breeding Bird Survey Trends and Annual Indices for Canada: How Do the New Hierarchical Bayesian Estimates Differ from Previous Estimates?, 119-134

Smith, P. Cory's Bittern, Ixobrychus "neoxenus" exilis: Morph, Mutant, or Mixed Bag? 350-357

Somateria mollissima, 235

Song, 408

Bird, 269

Sorex hoyii, 204

Soricomorpha, 25

Spiders, 363

Spruce, White, 243

Starvation, 145

Stenhouse, G.B., 223

Strait of Georgia, 57

Streams, 111

Strix varia, 38

Subspecies, Parapatric, 377

Succession, 243

Survey,

Aerial, 235

Audio, 39, 50, 393

Auditory, 151

Transect, 38, 50, 165, 400

Visual, 173, 179, 235, 341, 363, 385, 393

Swanson, H.K., 260

Swarth, C.W., and W. Bleeker. Observations of the Summer Birds of Tukarak Island (Belcher Islands, Nunavut), Nastapoka Islands (Nunavut), and Lac Guillaume-Delisle (Northern Quebec), 385-392

Switch, Food Plant, 358Telemetry, GPS, 80, 223

Tennessee, Southern, 191

Territorial Park, Tombstone, 265

Thamnophis sirtalis pallidulus, 63

Thickness, Eggshell, 72

Thuja occidentalis, 243

Tracks, Winter, 272

Trait, Recessive, 63

Transmitter,

Acoustic, 260

GPS, 223

Trap (s),
Aquatic Insect Emergence, 200

Light, 158

Orientation, 191

Pitfall, 363

Sherman Live, 191

Snap, 265

Success, 191

Susceptibility, 191

Tribute, 84, 276, 289, 431

Trout, Lake, 260

Tundra, Alpine, 265

Turner, B.C., 235

Turner, D.M., 341

Turtles, 179

Midland Painted, 179

Snapping, 179

Twine, Baling, 173

Uria aalge, 72

Ursus arctos, 223

Vaccinium scoparium, 400

Variation,

Decadal, 57

Ecological, 377

Interannual, 57

Vegetation, Woody, 243

Vocalization, 269

Voles, 25, 393

Townsend's, 393

Warbler,

Mourning, 408

Yellow, 44

Water, Chemistry, 1

Weasels, 25

Weeber, R.C., 1

Weir, 260

Wetlands, Prairie, 200

Whiklo, T.M., and J.R. Duncan. Characteristics of Barred Owl (Strix varia) Nest Sites in Manitoba, Canada, 38-43

Wilderness Area, Wilmore, 223

Wildfire, 400

Witch, Black, 77

Wolcott, D.M., M.R. Ackerman, M.L. Kennedy. Assessing Capture Success of Small Mammals Due to Trap Orientation in Field-Forest Edge Habitat, 191-194

Wolf, Gray, 189

Woodcock, T.S., 77

Yukon, 341

Aklavik, 377

Fort McPherson, 377

Inuvik, 377

Ogilvie Mountains, 265

Tsiigehtchic, 377

Zooplankton, 1

Zurbrigg, E., I. Brodo, J. Cipriani, C. Hanrahan, and A. MacKenzie. The Ottawa Field-Naturalists' Club Awards for 2013, presented April 2014, 432-434 


\section{Index to Book Reviews}

\section{Botany}

Applegate, R.D. "Trees of Eastern North America" by Gil Nelson et al., 2014, 426

Bickerton, H.J. "Field Manual of Michigan Flora" by E.G. Voss and A.A. Reznicek, 2013, 99

Catling, P. "Plants of Southern Ontario, Trees, Shrubs, Wildflowers, Grasses, Ferns and Aquatic Plants" by Richard Dickinson and France Royer, 2014, 305-306

Haber, E. "Plantes de milieux humides et de bord de mer du Québec et des Maritimes" by Martine Lapointe et al., 2014, 424-425

Smith, C.M. "North Pacific Temperate Rainforests: Ecology and Conservation" by Gordon $\mathrm{H}$. Orians and John W. Schoen, 2013, 100-101

\section{Environment}

Applegate, R.D. "Ecology $3^{\text {rd }}$ Edition" by Michael Cain et al., 2014, 214

John, R. "The Crossley ID Guide to Britain and Ireland" by Richard Crossley and Dominic Couzens, 2013, 95

McBride, B. "The Once and Future Great Lakes Country: An Ecological History" by John Riley, 2013, 215

\section{Other}

Beaudoin, A.B. "Bootstrap Geologist: My Life in Science" by Gene Shinn, 2013, 103-104

Beaudoin, A.B. "Alfred Russel Wallace (2013) On the Organic Law of Change: A Facsimile Edition and Annotated Transcription of Alfred Russel Wallace's Species Notebook of 18551859", 2013, 105-107

Fox, G. "The Dismal State of the Great Lakes" by James P. Ludwig, 2013, 307-310

Haber, E. "The Real Weed Man: Portrait of Canadian Botanist Gerald A. Mulligan" by Julie Mulligan, 2014, 426-427

Houston, C.S. "A Love Affair With the Birds: The Life of Thomas Sadler Roberts" by Sue Leaf, 2013, 101-103

John, R., New Titles, 108-109, 216, 311-313, 429430

John, R. "Bird Lady - A Lifelong Love Affair with Birds" by Elizabeth Le Geyt, 2014, 306-307

Sander-Regier, R. "The Once and Future World: Nature as it was, as it is, and as it could be" by J.B. MacKinnon, 2013, 427-428

Seburn, D. "Tracks and Shadows: Field Biology as an Art" by Harry W. Green, 2013, 104-105

\section{Zoology}

Bocking, E. "The Fish in the Forest: Salmon and the Web of Life" by Dale Stokes and Doc White, 2014, 421-422

Brooks, R. "Snapper" by Brian Kimberling, 2013, 93-95

Brooks, R. "A Feathered River Across the Sky. The Passenger Pigeon's Flight to Extinction" by Joel Greenberg, 2014, 298-303

Cook, F.R. "A Pocket Guide to Salamanders of Pennsylvania" by Walter E. Meshaka, Jr., and Joseph T. Collins, 2012, 93

Cook, F.R. "Amphibian Conservation - Global Evidence for the Effects of Interventions" by Rebecca K. Smith and William J. Sutherland, 2014, 416

Cook, F.R. "Amphibians and Reptiles in Minnesota" by John J. Moriarty and Carol D. Hall, 2014, 416-417

Cook, F.R. "Amphibians of Ohio" by Ralph A. Pfingsten et al., 2013, 417-418

Foster, R. "Animals of the Serengeti and Ngorongoro Conservation Area" by Adam S. Kennedy and Vicki Kennedy, 2014, 207-208

Foster, R. "Birds of the Serengeti and Ngorongoro Conservation Area" by Adam S. Kennedy, 2014, 207-208

Foster, R. "Beetles of Eastern North America" by Arthur V. Evans, 2014, 295-296

Foster, R. "Birds of the Kenya's Rift Valley" by Adam S. Kennedy, 2014, 296-297

Gawn, M. "The Warbler Guide" by Tom Stephenson and Scott Whittle, 2013, 96

John, R. "Rare Birds of North America" by Steve Howell, 2013, 209

John, R. "Dolphin" by Alan Rauch, 2014, 211-212

John, R. "The Amazing World of Flyingfish" by Steve N.G. Howell, 2014, 297

John, R. "A Field Guide to the Larger Mammals of Tanzania" by Charles Foley et al., 2014, 297298

John, R. “A Sparrowhawk's Lament - How British Birds of Prey are Faring" by David Cobham, 2014, 303-304

John, R. "Illustrated Checklist of the Birds of the World - Non Passerines" by Josep del Hoyo et al., 2014, 418-419

Lim, B.K. "Into the Night: Tales of Nocturnal Wildlife Expeditions" by Rick A. Adams, 2013, 91-92

O’Neill, J. "Yellowstone Wildlife: Ecology and Natural History of the Greater Yellowstone 
Ecosystem" by Paul A. Johnsgard, 2013, 9697

Sander-Regier, R. "Owls” by Marianne Taylor, 2012, 92

Seburn, D. "Biology and Conservation of North American Tortoises" by David R. Rostal et al., 2014, 422

Smith, C.M. "Life on the Rocks: A Portrait of the American Mountain Goat" by Bruce L. Smith, 2014, 420
Way, J. "Yellowstone Wildlife: Ecology and Natural History of the Greater Yellowstone Ecosystem" by Paul A. Johnsgard, 2013, 97-98

Way, J. "Deer" by John Fletcher, 2014, 210-211

Way, J. "Wild Again: The Struggle to Save the Black-footed Ferret" by David Jachowski, 2014, 212-214

Way, J. "Societies of Wolves and Free-ranging Dogs" by Stephen Spotte, 2012, 423-424 